\title{
PENGARUH PENGGUNAAN SISTEM INFORMASI MANAJEMEN TERHADAP KUALITAS LAPORAN KEUANGAN PADA PT. TELKOM KOTA PALOPO
}

\author{
Irawati $^{1}$, Salju $^{2}$, Hapid ${ }^{3}$ \\ Email: 1)irhawati1995@gmail.com, ${ }^{2}$ saljusanuddin68@gmail.com ${ }^{3)}$ hapid@ @stiem.ac.id \\ ${ }^{1,2)}$ Prodi Manajemen, Sekolah Tinggi Imu Ekonomi Muhammadiyah Palopo \\ ${ }^{3)}$ Prodi Ilmu Pembangunan, Sekolah Tinggi Imu Ekonomi Muhammadiyah Palopo
}

\begin{abstract}
Abstrak
Penelitian ini bertujuan untuk mengetahui pengaruh penggunaan sistem informasi manajemen terhadap kualitas laporan keuangan pada PT. Telkom kota palopo. Jenis penelitian yang dilakukan adalah penelitian deskriptif kuantitatif. Penelitian ini dilakukan dengan mengambil objek pada karyawan PT. Telkom kota palopo. Jenis data yang digunakan dalam penelitian ini adalah data primer.Pengumpulan data dilakukan dengan menggunakan kuesioner.Metode analisis data mengggunakan analisis deskriptif. Populasi dalam penelitian ini adalah karyawan atau staf yang berada pada PT. Telkom kota palopo. Dari total 45 kuesioner yang tersebar hanya ada 45 kuesioner dari responden yang kembali dan dapat diolah. Metode analisis yang digunakan dalam penelitian untuk mengetahui antar variabel adalah analisis regresi sederhana dan pengujian hipotesis dengan bantuan software spss 21 for windows untuk mengolah data. Berdasarkaan hasil analisis terdapat pengaruh penggunaan sistem informasi manajemen terhadap kualitas laporan keuangan dengan nilai signifikan sebesar 0,000 lebih kecil dari tingkat alpha 0,05.
\end{abstract}

Kata kunci : Penggunaan Sistem Informasi Manajemen Dan Kualitas Laporan Keuangan

\section{PENDAHULUAN}

Setelah perkembangan teknologi informasi yang demikian pesatnya, maka semakin banyaklah perusahaan di Indonesia menerapkan Sistem Informasi Manajemen (SIM).Karena mereka mulai menyadari SIM sangat besar manfaatnya bagi peningkatan kinerja organisasi. Perusahaan yang tidak mengikuti perkembangan teknologi informasi pada dewasa ini tidak akan unggul di dalam persaingan. Ukuran penggunaan sistem berhubungan erat dengan pendekatan kepuasan pemakai.Banyak peneliti mengakui bahwa kepuasan pemakai SIM merupakan indikator yang penting dalam menentukan keberhasilan dalam mendesain dan mengimplementasikan SIM.

Akan tetapi sebenarnya sistem informasi manajemen telah ada sebelum adanya perkembangan teknologi informasi (teknologi komputer), SIM telah digunakan oleh para pimpinan organisasi atau perusahaan, dalam upaya pengambilan keputusan walaupun masih terbatas.Saat itu, proses pengambilan keputusan yang dilakukan masih sangat sederhana.Segala sesuatunya masih berjalan secara manual dan masih lamban karena semua data yang tersimpan dalam bentuk lembaran-lembaran arsip yang bermacam ragam. Sehingga dimana pimpinan memerlukan suatu informasi yang berhubungan dengan sesuatu dan harus diputuskan atau diambil kebijakan, maka tidak ada cara selain membongkar semua arsip yang dibutuhkan. Kadangkala jika arsip tersebut telah ditemukan tulisannya sudah kabur, kertasnya sudah kusam, atau bahkan mungkin sudah rusak karena dimakan rayap atau kutu buku dan sejenisnya. Pendek kata, proses pencarian arsip dan dokumen yang dibutuhkan sebagai dasar dari pengambilan keputusan bagi sang pimpinan sangatlah lamban dan membutuhkan waktu yang lama.

Apabila berbicara tentang Sistem Informasi Manajemen, maka yang diingat adalah komputer dengan sebuah sistem yang saling tersambung dengan berbagai jaringan dalam komputer tersebut. Persepsi seperti ini tentu saja tidaklah semuanya benar, karena teknologi komputer hanyalah sebuah wadah atau fasilitas, yang kehadirannya mempermudah proses dalam Sistem Informasi Manajemen, sedangkan prinsip kerja dan basis dari SIM itu sendiri adalah ilmu manajemen, karena memang SIM itu lahir dari manajemen. Artinya, tanpa adanya manajemen maka SIM itu sendiri sesungguhnya tidak ada. Adapun komputer, kehadirannya seperti proses reaksi kimia bagi katalisator, katalisator dapat mempercepat proses reaksi kimiawi, tetapi dia sendiri bukanlah zat kimianya.

Sistem Informasi Manajemen menurut Raymond McLeod Jr(1996:54) mengemukakan bahwa SIM adalah sebagai suatu sistem berbasis komputer yang menyediakan informasi bagi beberapapemakai dengan kebutuhan serupa. 
Berdasarkan uraian pada latar belakang masalah tersebut, maka penelitian ini dapat dirumuskan sebagai berikut apakah sistem informasi manajemen berpengaruh positif dan signifikan terhadap kualitas laporan keuangan pada PT. Telkom Kota PalopoSejalan dengan pokok permasalahan tersebut, maka tujuan yang hendak dicapai dalam penelitian ini adalah untuk mengetahui pengaruh penggunaan sistem informasi manajemen terhadap kualitas laporan keuangan pada PT. Telkom Kota Palopo. Penelitian ini diharapkan dapat memberikan manfaat teoritis dan Praktis adapun manfaat teoritis penelitian ini diharapkan dapat Menambah wawasan dan pengalaman bagi peneliti mengenai pengaruh sistem informasi manajemen terhadap kualitas laporan keuangan pada PT. Telkom Kota Palopo.Sedangkan Manfaat Praktis Bagi penulis Penelitian ini, diharapkan dapat menghimpun informasi sebagai bahan sumbangan pemikiran bagi PT. Telkom Kota Palopo guna meningkatkan kinerja dalam penyusunan laporan keuangan.

\section{TINJAUAN PUSTAKA}

\section{Teori Sistem Informasi Manajemen (SIM)}

Menurut Mcleod dan Schell (2001:15) sebagai berukut : "SIM merupakan sistem yang berbasis komputer, jaringan lainnya yang dapat menyediakan informasi bagi beberapa pemakai guna mendukung fungsi-fungsi manajemen dan fungsi pengambilan keputusan". Menurut Ibnu Syamsi (2000:8) menyatakan bahwa sistem informasi manajemen (SIM) merupakan jaringan informasi yang dibutuhkan pimpinan dalam menjalankan tugasnya, terutama dalam mengambil keputusan.Menurut ZulkifliAmsyah (1997:23) menyatakan bahwa: "SIM merupakan cara-cara mengelola pekerjaan informasi dengan mengunakan pendekatan sistem yang berdasarkan pada prinsipprinsip manajemen”.Menurut (Jogiyanto 2005:14) sistem informasi manajemen (management information systems) merupakan penerapan sistem informasi di dalam organisasi untuk mendukung informasi-informasi yang dibutuhkan oleh semua tingkatan manajemen.

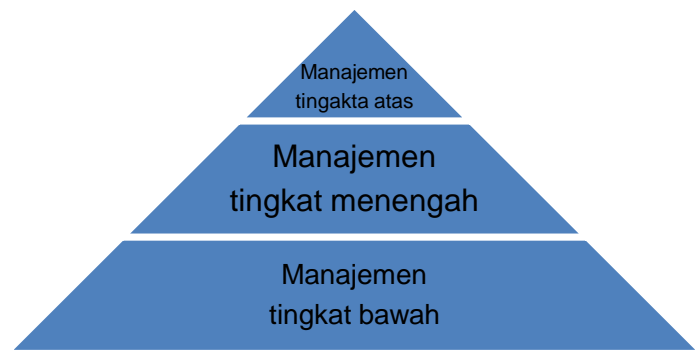

Gambar 1 : Tingkatan Manajemen

1) Manajemen tingkat atas (top level management) terdiri dari : Direkturutama (president), Direktur (vice manager) dan Eksekutif lainnya. (Jogiyanto 2005:16)
2) Manajemen tingkat menengah (middlelevel management) terdiri dari : manajer-manajerdivisi dan manajer-manajercabang. (Jogiyanto, 2005:16)

3) Manajemen tingkat bawah (lower level management) disebut operatingmanagement meliputi mandor danpengawas. (Jogiyanto 2005:16)

\section{Komponen Sistem Informasi Manajemen}

Komponen Sistem Informasi ManajemenMenurut Susanto (2004:34) komponen dalam sebuah informasi akuntansi yang terintegrasi dalam sebuah sistem yang bekerja secara harmonis dalam rangka menghasilkan informasi yang dapat diandalkan oleh para pemakai.Dalam konsep sistem informasi manajemen yang harus diintegrasikan adalah semua unsur dan subunsur yang terkait dalam membentuk suatu sistem informasi manajemenyang berkualitas.Unsur-unsur tersebut juga disebut sebagai komponen sistem informasi akuntansi yang terdiri dari hardware, software, brainware, prosedur, databasedan jaringan komunikasi.

Adapun komponen sistem informasi manajemenmenurut Susanto (2004:34) yaitu;

1. Hardware (perangkat keras), peralatan phisik yang dapat digunakan untuk mengumpulkan, memasukkan, memproses, menyimpan, dan mengeluarkan hasil pengolahan data dalam bentuk informasi.

2. Software (perangkat lunak), kumpulan dari programprogram yang digunakan untuk menjalankan komputer atau aplikasi tertentu pada computer.

3. Brainware, sumber daya manusia yaitu bagian terpenting dari komponen sistem informasi manajemen,

4. Prosedur yaitu rangkaian aktivitas atau kegiatan yang dilakukan secara berulang-ulang dengan cara yang sama.

5. Basis data yaitu suatu pengorganisasian sekumpulan data yang saling terkait sehingga memudahkan proses pencarian informasi, dan Jaringan komputer dan komunikasi data.

\section{Pengertian Kualitas Laporan Keuangan}

Kualitas laporan keuangan adalah sejauh mana laporan keuangan yang disajikan menunjukan informasi yang benar dan jujur.Kualitas laporan keuangan berguna sebagai dasar pengambilan keputusan ekonomi bagi pihak yang berkepentingan. Kualitas laporan keuangan dengan berbagai pengukurannya, umumnya digunakan dalam keputusan investasi, perjanjian kompensasi dan persyaratan hutang, keputusan kontrak yang berdasar kualitas laporan keuangan yang rendah akan mempengaruhi transfer kesejahteraan yang tidak diinginkan. (Hayyuning Tyas,2011:21). Menurut Lyn M. Fraser dan Aileen Ormiston dialih bahasakan oleh Sam Setyautama (2008:11), mengemukakan bahwa kualitas laporan keuangan adalah sebagai berikut:"Kualitas laporan keuangan adalah idealnya laporan keuangan harusnya mencerminkan gambaran yang akurat tentang kondisi keuangan dan kinerja perusahaan. Informasinya harus berguna untuk menilai 
masa lalu dan masa yang akan datang. Semakin tajam dan semakin jelas gambar yang disajikan lewat data financial, dan semakin mendekati kebenaran."

Laporan keuangan perusahaan akan menunjukan seberapa besar tingkat keberhasilan perusahaan dalam menjalankan aktivitas bisnisnya. Apabila laporan keuangan perusahaan berkualitas baik maka dapat dikatakan para pelaku usaha berhasil dalam menjalankan kegiatan usahanya dan telah mampu meminimalkan resiko penyimpangan yang dapat dilakukan oleh pihak-pihak tertentu.

Ada beberapa definisi dari Laporan keuangan baik laporan keuangan secara umum maupun laporan keuangan bagi institusi pemerintahan. Heri (2012:2) mendefinisikan laporan keuangan sebagai berikut:"Laporan keuangan adalah hasil dari proses akuntansi yang dapat digunakan sebagai alat untuk mengkomunikasikan data keuangan atau aktivitas perusahaan kepada pihak pihak yang berkepentingan yang menunjukan kondisi kesehatan keuangan perusahaan dan kinerja perusahaan".

\section{Jenis Laporan Keuangan}

Menurut Sukrisno Agoes dan Estralita Trisnawati (2012:3), laporan keuangan terbagi menjadi seperti berikut ini:

\section{Laporan Laba Rugi}

Laporan laba rugi adalah laporankeuangan yang menggambarkan hasil usaha perusahaan dalam suatu periode tertentu.Laporan ini menunjukkan pendapatan dan beban selama periode waktu tertentu, misalnya sebulan atau setahun.Jika jumlah pendapatan lebih besar dari jumlah biaya, perusahaan dikatakan laba.Sebaliknya bila jumlah pendapatan lebih kecil dari jumlah biaya, perusahaan dikatakan rugi.

2. Laporan Perubahan Ekuitas

Laporan perubahan ekuitas adalah laporan yang menunjukkan perubahan ekuitas pemilik yang terjadi selama periode waktu tertentu, misalnya sebulan atau setahun.Laporan ini dibuat setelah laporan laba atau rugi, tetapi sebelum neraca, karena jumlah ekuitas pemilik pada akhir periode harus dilaporkan dalam neraca.

3. Neraca

Neraca adalah suatu daftar aset, kewajiban, dan ekuitas pemilik pada tanggal tertentu, misalnya pada akhir bulan atau akhir tahun.Ada dua bentuk neraca, yaitu bentuk akun dan bentuk laporan.

4. Laporan Arus Kas

Laporan arus kas adalah laporan yang menunjukkan penerimaan dan pembayaran kas selama periode waktu tertentu, misalnya sebulan atau setahun. Laporan arus kas terdiri dari tiga bagian, yaitu:

a. Arus kas dari aktivitas operasi, merupakan arus kas dari transaksi yang memengaruhi laba bersih.

b. Arus kas dari aktivitas investasi, merupakan arus kas dari transaksi yang memengaruhi investasi dan non aset lancar. c. Arus kas dari aktivitas pendanaan, merupakan arus kas dari transaksi yang memengaruhi ekuitas dan kewajiban jangka panjang.

5. Laporan Catatan Atas Laporan Keuangan

Laporan catatan atas laporan keuangan merupakan laporan yang memberikan informasi apabila ada laporan keuangan yang memerlukan penjelasan tertentu.

\section{Sifat Laporan Keuangan}

Menurut Kasmir (2008 : 12) laporan keuangan memiliki dua sifat yaitu :

1. Bersifat historis, artinya bahwa laporan keuangan dibuat dan disusun dari data masa lalu atau masa yang sudah lewat dari masa sekarang.

2. Bersifat menyeluruh, artinya laporan keuangan disusun sesuai dengan standar yang telah ditetapkan.

\section{Karakteristik Laporan Keuangan}

Menurut Dwi Prastowo (2011:7), karakteristikkualitatif laporan keuangan merupakan ciri khas yang membuat informasi dalam laporan keuangan berguna bagi para pemakai dalam pengambilan keputusan ekonomi. Karakteristik kualitatif laporan keuangan ini meliputi:

1. Dapat dipahami

Kualitas penting informasi yang ditampung dalam laporan keuangan adalah kemudahannya untuk segera dapat dipahami oleh pemakai.Untuk maksud ini, pemakai diasumsikan memiliki pengetahuan yang memadai tentang aktivitas ekonomi dan bisnis, akuntansi, serta kemauan untuk mempelajari informasi dengan ketekunan yang wajar. Namun demikian, informasi kompleks yang seharusnya dimasukkan dalam laporan keuangan tidak dapat dikeluarkan hanya atas dasar pertimbangan bahwa informasi tesebut terlalu sulit untuk dapat dipahami oleh pemakai tertentu.

2. Relevan

Informasi harus relevan untuk memenuhi kebutuhan pemakai dalam proses pengambilan keputusan. Informasi memiliki kualitas relevan kalau dapat mempengaruhi keputusan ekonomi pemakai dengan membantu mereka mengevaluasi peristiwa masa lalu, masa kini atau masa depan, menegaskan, atau mengkoreksi hasil evaluasi mereka dimasa lalu. Peran informasi dalam peramalan (predictive) dan penegasan (confirmatory) berkaitan satu sama lain. Misalnya informasi struktur dan besarnya aset yang dimiliki bermanfaat bagi pemakai ketika mereka berusaha meramalkan kemampuan perusahaan dalam memanfaatkan peluang dan bereaksi terhadap situasi yang merugikan. Informasi yang sama juga berperan dalam memberikan penegasan (confirmatory role) terhadap prediksi yang lalu, misalnya tentang bagaimana struktur keuangan perusahaan diharapkan tersusun atau tentang hasil dari operasi yang direncanakan. Informasi posisi keuangan dan kinerja di masa lalu seringkali digunakan sebagai dasar untuk memprediksi posisi keuangan dan kinerja masa depan dan hal-hal lain yang langsung menarik perhatian pemakai, seperti 
pembayaran dividen dan upah, pergerakan harga sekuritas dan kemampuan perusahaan untuk memenuhi komitmennya ketika jatuh tempo. Untuk memiliki nilai prediktif, informasi tidak perlu harus dalam bentuk ramalan eksplisit.Namun demikian, kemampuan laporan keuangan untuk membuat prediksi dapat ditingkatkan dengan penampilan informasi tentang transaksi dan peristiwa masa lalu.Misalnya nilai prediktif laporan laba-rugi dapat ditingkatkan kalau akun-akun penghasilan atau badan yang tidak biasa, abnormal dan jarang terjadi diungkapkan secara terpisah.

\section{Keandalan}

Informasi juga harus andal (reliable). Informasi memiliki kualitas andal jika bebas dari pengertian yang menyesatkan, material, dan dapat diandalkan pemakaiannya sebagai penyajian yang tulus atau jujur dari yang seharusnya disajikan atau yang secara wajar diharapkan dapat disajikan. Informasi mungkin relevan tetapi jika hakekat atau penyajiannya tidak dapat diandalkan maka penggunaan informasi tersebut secara potensial dapat menyesatkan. Misalnya jika tindakan hukum masih dipersengkatakan, mungkin tidak tepat bagi perusahaan untuk mengakui jumlah seluruh tuntutan tersebut dalam neraca, meskipun mungkin tepat untuk mengungkapkan jumlah serta keadaan dari tuntutan tersebut.

a) Penyajian jujur

Informasi harus digambarkan dengan jujur transaksi serta peristiwa lainnya yang seharusnya disajikan atau yang secara wajar dapat diharapkan untuk disajikan.Jadi misalnya, neraca harus menggambarkan dengan jujur transaksi serta peristiwa lainnya dalam bentuk aset, kewajiban dan ekuitas perusahaan pada tanggal pelaporan yang memenuhi kriteria pengakuan.

b) Substansi mengungguli bentuk

Jika informasi dimaksudkan untuk menyajikan dengan jujur transaksi serta peristiwa lain yang seharusnya disajikan, maka peristiwa tersebut perlu dicatat dan disajikan sesuai dengan substansi dan realitas ekonomi dan bukan hanya bentuk hukumnya.

c) Netralitas

Informasi harus diarahkan pada kebutuhan dan keinginan pihak tertentu. Tidak boleh ada usaha untuk menyajikan informasi yang menguntungkan beberapa pihak, sementara hal tersebut akan merugikan pihak lain yang mempunyai kepentingan yang berlawanan.

d) Pertimbangan sehat

Penyusunan laporan keuangan ada kalanya menghadapi ketidakpastian peristiwa dan keadaan tertentu, seperti ketertagihan piutang yang diragukan, perkiraan masa manfaat prabrik serta peralatan, dan tuntutan atas jaminan garansi yang mungkin timbul.Ketidakpastian semacam itu diakui dengan mengungkapkan hakekat serta tingkatnya dan dengan menggunakan pertimbangan sehat dalam penyusunan laporan keuangan.Pertimbangan mengandung unsur kehati-hatian pada saat melakukan perkiraan dalam kondisi ketidakpastian, sehingga aset atau penghasilan tidak dinyatakan terlalu rendah. Namun demikian, penggunaan pertimbangan sehat tidak diperkenankan, misalnya pembentukan cadangan tersembunyi atau penyisihan berlebihan dan sengaja menetapkan aset atau penghasilan yang lebih rendah atau pencatatan kewajiban atau beban yang lebih tinggi, sehingga laporan keuangan menjadi tak netral, dan karena itu tidak memiliki kualitas andal.

e) Kelengkapan

Informasi dalam laporan keuangan harus lengkap dalam batasan materialitas dan beban. Kesengajaan untuk tidak mengungkapkan mengakibatkan informasi menjadi tidak benar atau menyesatkan dan karena itu tidak dapat diandalkan dan tidak sempurna ditinjau dari segi relevansinya.

4. Dapat dibandingkan

Pemakai harus dapat membandingkan laporan keuangan perusahaan antara periode untuk mengidentifikasi kecenderungan posisi dan kinerja keuangan. Pemakai juga harus dapat memperbandingkan laporan keuangan antara perusahaan untuk mengevaluasi posisi keuangan secara relatif. Oleh karena itu, pengukuran dan penyajian dampak keuangan, transaksi, dan peristiwa lain yang serupa harus dilakukan secara konsisten untuk perushaan bersangkutan, antar periode perusahaan yang sama dan untuk perusahaan yang berbeda.

Penelitian ini bertujuan untuk mengetahui ada atau tidaknya pengaruh antara variabel terikat yaitu Penggunaan sistem informasi manajemendengan variabel bebas yaituKualitas laporan keuangan. Kerangka pemikiran yang digunakan untuk merumuskan hipotesis dalam penelitian ini adalah sebagai berikut ini:

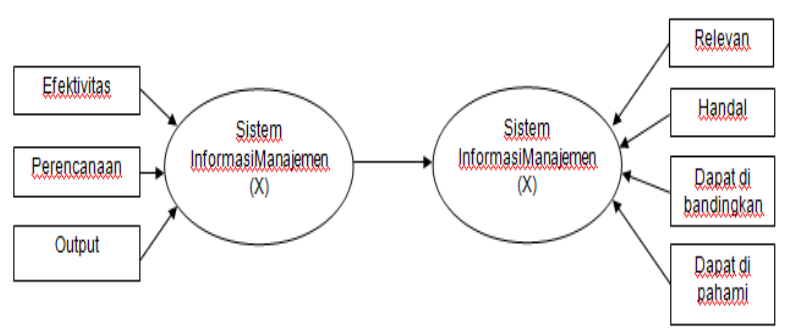

Gambar 2. Kerangka Penelitian

\section{METODE}

Jenis data yang digunakan dalam penelitian ini yakni data kuantitatif yang berupa hasil kuesioner. Sumber datayang digunakan dalam penelitian ini yakni data primer dan sekunder dimana data primer yang berupajawaban responden terhadap pernyataan dalam 
kuesioner yang dikumpulkan dari kantor PT. Telkom Kota Palopo. Sedangkan sumber sekunder adalah sumber data yang tidak langsung memberikan data kepada pengumpul data, misalnya lewat orang lain atau lewat dokumen. Populasi adalah keseluruhan kelompok orang, kejadian, atau hal minat yang ingin peneliti investigasi, sedangkan sampel adalah sebagian dari populasi, sampel terdiri atas sejumlah anggota yang dipilih dari populasi(Uma Sekaran,2006).Populasi dan sampel dalam penelitian ini adalah seluruh yang ada di PT. Telkom. Populasi dalam penelitian ini adalah 45 orang yang merupakan karyawan atau staff PT. Telkom Kota Palopo yang sekaligus dijadikan sampel pada penelitian ini. Kuesioner yang disebar sebanyak 45dan Kuesioneryang direspon atau dikembalikan sebanyak 45 kuesioner yang dapat diolah seluruhnya.

Adapun metode analisis data yang digunakan didalam penelitian ini yaitu analisis regresi sederhana dengan dibantu komputer melalui program SPSS Versi 21.

\section{HASIL DAN PEMBAHASAN}

\section{Analisis Regresi Linier Sederhana}

Perhitungan data dalam penelitian ini dilakukan dengan menggunakan program aplikasi statistik SPSS versi.21 dengan hasil sebagai berikut :

Tabel 1. Hasil Uji Regresi Linier Sederhana

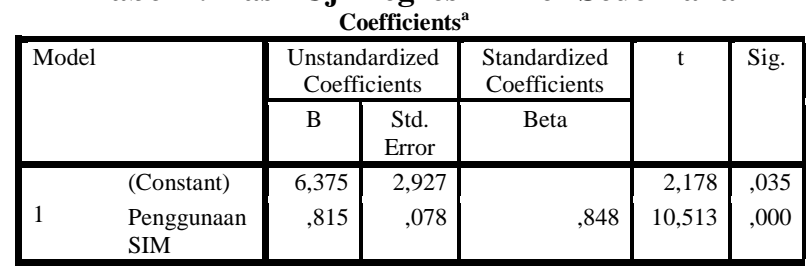

a. Dependent Variable: Kualitaslaporankeuangan

Sumber : Data Primer Diolah, 2017

Berdasarkan tabel 4.6 diatas didapat persamaan regresi linier sederhana sebagai berikut :

$\mathrm{Y}=6,375+0,815 \mathrm{X}$

a. 6,375 adalah konstanta yang artinya, apabila penggunaan sistem informasi manajemen (X) konstanta atau sama dengan 0 (nol) maka kualitas laporan keuangan (Y) sebesar 6,375 satuan.

b. 0,815 artinya apabila penggunaan sistem informasi manajemen meningkat sebesar 0,815 maka kualitas laporan keuangan akan naik sebesar satu satuan.

\section{Koefisiean Determinasi ( R Square)}

Selanjutnya melakukan koefisien determinasi $\left(\mathrm{R}^{2}\right)$.Koefisien ini menunjukkan seberapa besar presentase variabel independen (penggunaan sistem informasi manajemen) yang digunakan untuk menjelaskan variabel dependen (kualitas laporan keuangan). Berikut perhitungan koefisien determinasi $\left(\mathrm{R}^{2}\right)$ berdasarkan SPSS Ver. 21.00 :
Tabel 1. Koefisien Determinasi Model Summary ${ }^{b}$

\begin{tabular}{|c|c|c|c|c|}
\hline Model & $\mathrm{R}$ & R Square & $\begin{array}{c}\text { Adjusted R } \\
\text { Square }\end{array}$ & $\begin{array}{c}\text { Std. Error of } \\
\text { the Estimate }\end{array}$ \\
\hline 1 &, $848^{\mathrm{a}}$ &, 720 &, 713 & 1,395 \\
\hline
\end{tabular}

a. Predictors: (Constant), PenggunaanSIM

b. Dependent Variable: Kualitaslaporankeuangan

a. Angka $\mathrm{R}$ yang didapat pada tabel adalah sebesar 0,848 artinya korelasi antara variabel penggunaan sistem informasi manajemen dengan variabel kualitas laporan keuangan sebesar 0,848. Hal ini berarti terjadi hubungan yang sangat erat karena nilai mendekati 1.

b. $\mathrm{R}$ Square diperoleh sebesar 0,720 atau (72,0\%)yang berarti bahwa variabel Penggunaan sistem informasi manajemen berpengaruh sebesar $72,0 \%$ terhadap variabel kualitas laporan keuangan pada PT. Telkom kota palopo sedangkan sisanya sebesar $28,0 \%$ dipengaruhi oleh faktor lain yang tidak diteliti pada penelitian ini.

\section{Hasil Pengujian Hipotesis} Uji Parsial (Uji t)

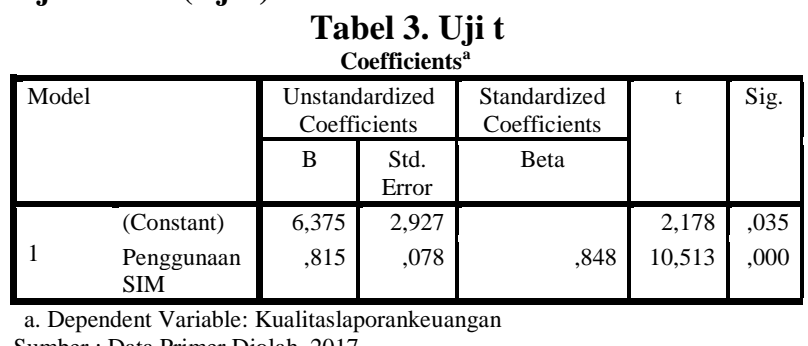
Sumber : Data Primer Diolah, 2017

Pengaruh dari penggunaan sistem informasi manajemen terhadap kualitas laporan keuangan pada PT. Telkom Kota Palopo dapat dilihat dari arah tanda dan tingkat signifikan. Hasil pengujian persial (uji t) antara penggunaan sistem informasi manajemen terhadap kualitas laporan keuangan menunjukka nilai $\mathrm{t}$ hitung sebesar 10,513 koefisien regresi sebesar 0,848 dan nilai probabilitas (sig) sebesar 0,000 yang tidak lebih besar dari 0,05 hal ini berarti bahwa penggunaan sistem informasi manajemen berpengaruh positif dan signifikan terhadap kualitas laporan keuangan.

Sesuai pengujian yang telah dilakukan menunjukkan hasil yaitu terdapat pengaruh yang positif 0,848 dengan tingkat signifikan 0,000 antara penggunaan sistem informasi manajemen terhadap kualitas laporan keuangan pada PT. Telkom Kota Palopo atau dapat dikatakan mempunyai kebenaran diatas 95\%. Hasil tersebut mendukung teori bahwa untuk dapat menghasilkan laporan keuangan yang relevan, handal, dapat dipahami dan dapat dibandingkan, perusahaan harus memiliki sistem informasi manajemen yang handal.Sistem informasi manajemen yang lemah menyebabkan laporan keuangan yang dihasilkan juga 
kurang handal dan kurang relevan untuk pembuatan keputusan.Oleh karena itu untuk dapat menghasilkan laporan keuangan yang berkualitas diperlukan penerapan sistem informasi manajemen yang baik.

Sistem informasi manajemen harus meningkatkan efektifitas, perencanaan yang baik untuk perusahaan dan menghasilkan output data atau informasi yang berguna bagi perusahaan. Agar laporan keuangan yang dihasilkan akan memiliki kualitas yang baik apabila pengguna sistem informasi manajemen mampu mengelola keuangan dengan jujur tanpa ada kecurangan didalamnya yang akan mengakibatkan dampat negatif untuk perusahaan. Laporan keuangan juga dijadikan bahan pertimbangan keputusan.Untuk itu pentingnya laporan keuangan sangat diperlukan agar dapat meningkatkan dalam pengambilan keputusan.Laporan keuangan yang berkualitas adalah laporan keuangan yang sudah memenuhi kriteria relevan, andal, dapat dipahami dan dapat dibandingkan.

\section{PENUTUP}

Penelitian ini meneliti tentang pengaruh penggunaan sistem informasi manajemen terhadap kualitas laporan keuangan.Variabel penelitian yang di gunakan adalah variabel dependen, yaitu kualitas laporan keuangan, sedangkan variabel independen yang di gunakan adalah penggunaan sistem informasi manajemen.Analisis dilakukan dengan menggunakan regresi linier sederhana dengan program package for social sciences (SPSS) ver.21.00.Subyek penelitian ini adalah PT. Telkom Kota Palopo tahun 2017. Dari total kuisioner yang disebar sebanyak 45 kuisioner dan kuisioner yang kembali dan dapat diolah sebanyak 45 kuisioner.

Berdasarkan hasil pengujian menggunakan regresi linier sedarhana dalam penelitian ini, maka dapat diambil kesimpulan sebagai berikut :

1. Berdasarkan hasil penelitian yang telah dilakukan pada PT. Telkom Kota Palopo, dapat disimpulkan bahwa penggunaan sistem informasi manajemen di PT. Telkom termasuk kategori sangat baik. Hal itu terlihat dari tanggapan responden mengenai penggunaan sistem informasi manajemen yang terdiri dari 8 pernyataan. Sehingga secara keseluruhan bahwa sistem informasi manajemen termasuk dalam kategori sangat baik.

2. Berdasarkan hasil penelitian yang telah dilakukan pada PT. Telkom Kota Palopo, dapat disimpulkan bahwa secara keseluruhan kualitas laporan keuangan termasuk kategori sangat baik. Hal itu terlihat dari tanggapan responden mengenai kualitas laporan keuangan. Laporan keuangan yang baik adalah laporan keuangan yang sudah memenuhi kriteria relevan, andal, dapat dipahami dan dapat dibandingkan. Sehingga dapat disimpulkan bahwa laporan keuangan di PT. Telkom merupakan laporan keuangan yang berkualitas.

3. Berdasarkan hasil pengujian regresi linier sederhana didapat nilai Coefficients $\mathrm{Y}=6,375+0,815 \mathrm{X}$ a. 6,375 adalah konstanta yang artinya, apabila penggunaan sistem informasi manajemen (X) konstanta atau sama dengan 0 (nol) maka kualitas laporan keuangan (Y) sebesar 6,375 satuan.

b. 0,815 artinya apabila penggunaan sistem informasi manajemen meningkat sebesar 0,815 maka kualitas laporan keuangan akan naik sebesar satu satuan.

Berdasarkan hasil uji perbandingan antara uji $\mathrm{f}$ dan uji t di peroleh hasil yang signifikan antara variabel bebas (penggunaan sistem informasi manajemen) terhadap variabel terikat (kualitas laporan keuangan) dengan membandingkan antara nilai signifikan 0,000 dengan $\alpha=0,05$. Dimana jika nilai signifikan $<\alpha$ maka variabel bebas berpengaruh signifikan terhadap variabel terikat. Berdasarkan hasil pengujian disimpulkan adanya pengaruh penggunaan sistem informasi manajemen terhadap kualitas laporan keuangan.Untuk itu khusus pada PT. Telkom Kota Palopo menjadi subjek dalam penelitian ini perlu memperhatikan sistem informasi manajemen yang digunakan, baik dalam memahami penggunaannya sehingga dalam mengelolah data keuangan dapat menghasilkan laporan keuangan yang berkualitas. Selain itu untuk peneliti selanjutnya diharapkan subjek penelitian ini tidak hanya berfokus pada satu perusahaan saja seperti dalam penelitian, yang berfokus hanya pada PT. Telkom saja, namun diharapkan peneliti selanjutnya dapat melakukan penelitian pada beberapa Perusahaan agar dapat menggambarkan secara umum dan luas mengenai pengaruh penggunaan sistem informasi manajemen terhadap kualitas laporan keuangan.

\section{DAFTAR PUSTAKA}

Amsyah, Zulkifli. (1997). Manajemen Sistem Informasi. Jakarta: Gramedia Pustaka

Agoes, Sukrisno dan Estralita Trisnawati. (2012). “Akuntansi Perpajakan”. Edisi 2 Revisi.Jakarta : Salemba empat.

Bens, D.A., and Monahan, S.J. (2002). Disclosure quality and the excess value ofdiversification.Dalam Journal of Accounting Research.

Daft, Richard L. 2002. Manajemen, Jilid 2. Jakarta: Salemba Empat

Dwi, Prastowo. (2011). Analisis Laporan Keuangan Konsep dan Aplikasi.Edisi Ketiga.Cetakan Pertama.Yogyakarta: UPP STIM YKPN

Hessel, Nogi S. Tangkilisan. (2007). Manajemen Publik. Jakarta: Grasindo

Hery. (2012). Analisis Laporan Keuangan. Jakarta: Bumi Aksara.

Istianingsih dan Setyo H Wijanto. (2008). Pengaruh Kualitas Sistem Informasi, Perceived Eserfulness, dan 
kualitas informasi Terhadap kepuasa Pengguna. Simposium Nasional Manajemen.

Iman, Abdurachman (2009) pengaruh kompetensi aparatur terhadap kualitas laporan keuangan organisasi perangkat daerah Bandung; Universitas padjadjaran.

Jogiyanto, (2005). (a) Jogianto HM, Analisa dan Design Sistem Informasi Andi Offset. Yogyakarta

(2005). (b) Sistem Teknologi Informasi. Yogyakarta.Penerbit Andi Offset.

Kusrini, M.kom dan Andri Koniyo, 2007, Tuntunan Praktis membangun sistem informasi Akuntansi Dengan Visual Basic dan Microsoft SQL Server, Yogyakarta : ANDI

Kasmir, 2008, Analisis Laporan Keuangan, Raja Grafindo Persada, Jakarta.

Laporan Keuangan,http://etalasepustaka.blogspot.co.id (diakses 10 Januari 2017).

Lyn M. Fraser dan Aileen ormiston, 2008. Memahami Laporan keuangan, Edisi Ketujuh, Indeks. Jakarta (Terjemahan).

Mulyono, I. 2009. Uji Empiris Model Kesuksesan Sistem Informasi Keuangan Daerah (SIKD) Dalam Rangka Peningkatan Transparansi Dan Akuntabilitas Keuangan Daerah. Jurnal Ilmiah Akuntansi SNA 12 Palembang
Mc.Loed dan Schell. 2001. Sistem Informasi Manajemen.(online), (Jurnal Capacity STIE AMKOP Makassar)

http://eprints.ums.ac.id/12619/3/Ghilar_Adhitya_Bab_I. pdf (diakses 25 Desember 2016)

Pradikto, Aryo. 2008. Dampak Kualitas Produk Informasi Kepuasan Kerja Pengguna Sistem Informasi Manajemen Kota Jogjakarta.Skripsi. Universitas Islam Indonesia: Yogyakarta

Raymond Mcleod, Jr., 1996, Sistem Informasi Manajemen, Prenhallindo, Jakarta.

Syamsi, Ibnu. 2000. Pengambilan Keputusan dan Sistem Informasi. Jakarta. Bumi Aksara.

Sutabri, Tata .2005.Sistem Informasi Manajemen.2005. Jakarta.

Susanto, 2004, Sistem Informasi Akuntansi Edisi Pertama. Lingga Jaya Bandung.

Scott, George M.2001. "Prinsip-prinsip Sistem Informasi Manajemen"Terjemahanoleh Achmad Nashir Budiman.Jakarta : PT Raja Grafindo Persada.

Sugiyono. 2012. Metode Penelitian Kuantitatif Kualitatif dan $R \& B$. Bandung: Alfabeta

Zulaikha dan Radityo, Dody. 2008. "Kesuksesan Pengembangan Sistem Informasi: Sebuah Kajian Empirik dengan DeLone and MacLean Model" Jurnal MAKSI. 